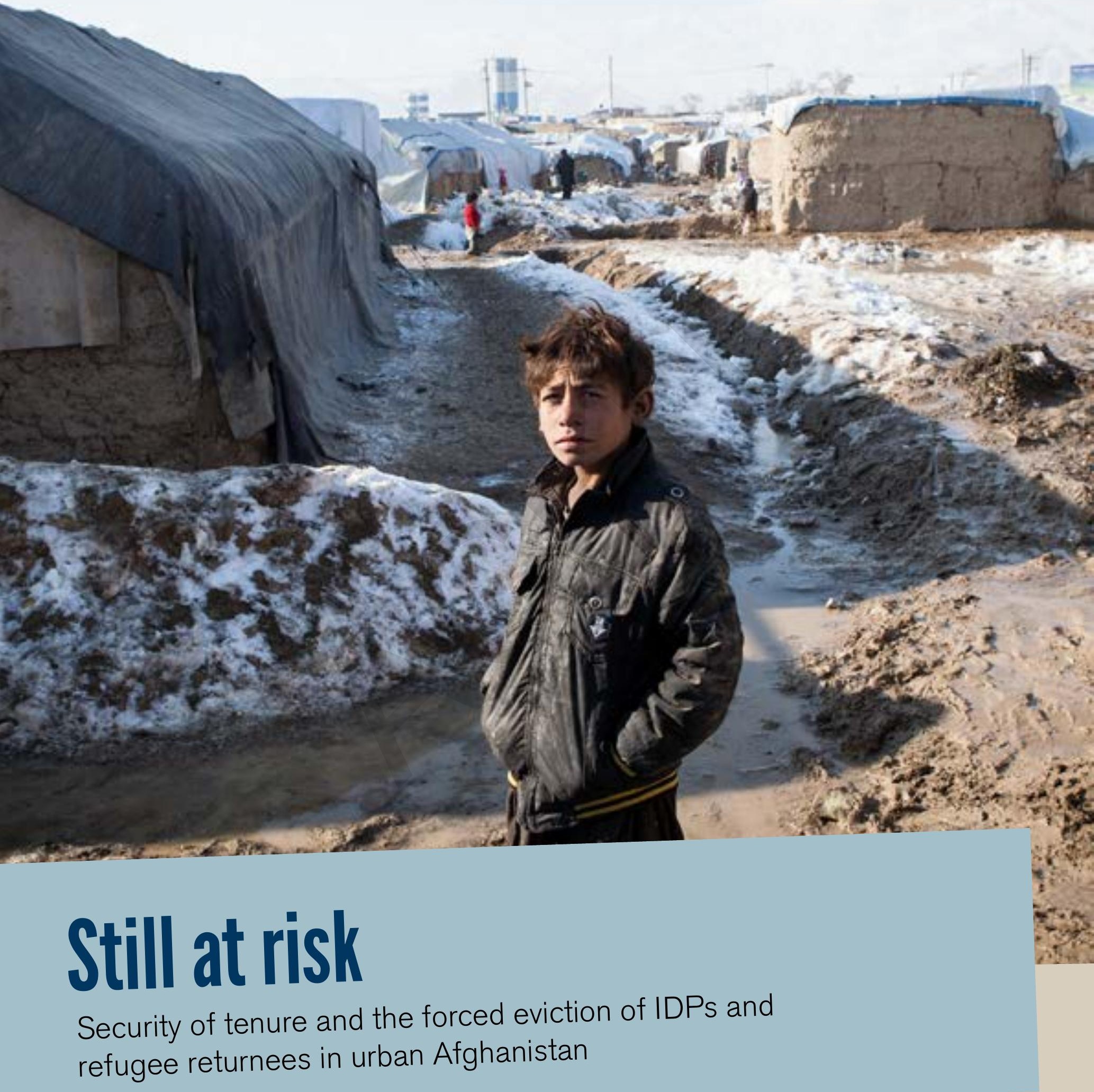




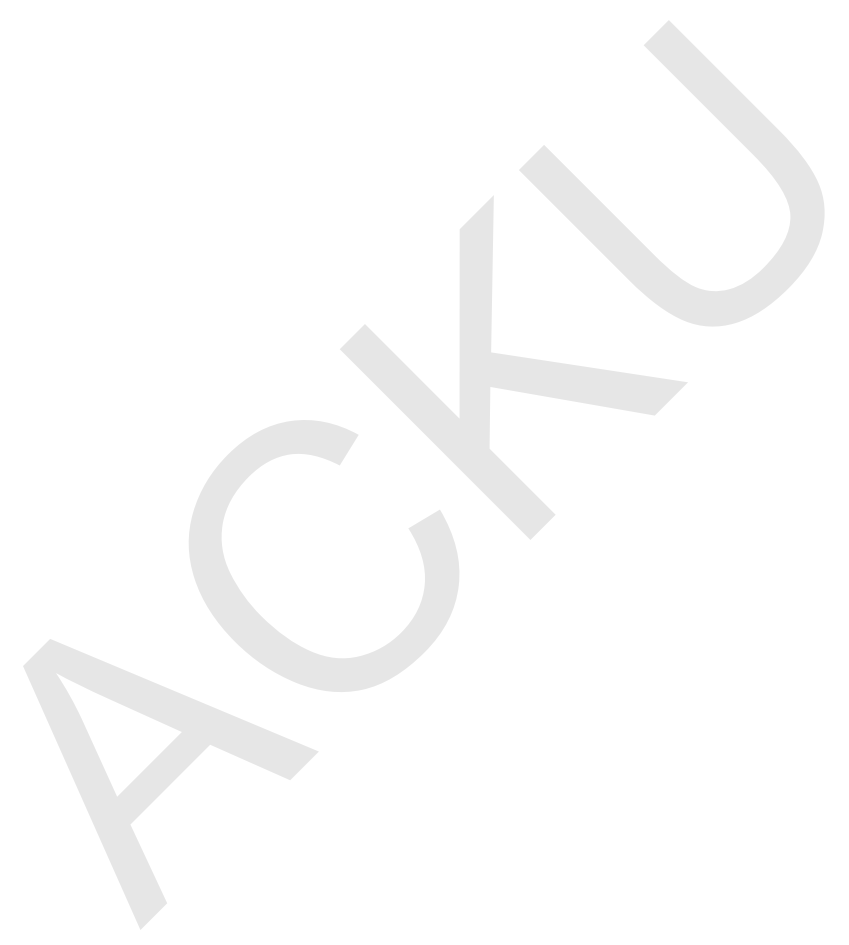




\section{Still at risk}

Security of tenure and the forced eviction of IDPs and refugee returnees in urban Afghanistan

February 2014 


\section{Acknowledgements}

This report was developed and written by Caroline Howard (Afghanistan Country Analyst, IDMC) and Jelena Madzarevic (Housing, Land and Property Advisor, NRC Afghanistan).

Special thanks to NRC Afghanistan Information, Counselling and Legal Assistance (ICLA) colleagues for their invaluable assistance in the collection and analysis of case information. Thanks also to Barbara McCallin, Senior HLP Advisor at IDMC; Monica Sanchez-Bermudez, NRC Oslo ICLA Advisor; Roel Debruyne, Protection and Advocacy Manager, NRC Afghanistan; Shoba Rao and Jan Turkstra of UN-HABITAT Afghanistan and Susan Schmeidl and Peyton Cooke from The Liaison Office for their advice and review of the report at different stages. Sven Richters, Michael Simpson, Frank Smith and Wesli Turner at IDMC provided further research assistance and comments.

IDMC would also like to thank all those who made time to meet and talk to IDMC researchers in the field.

Finally, thanks to Tim Morris for editorial assistance.

Cover photo: An internally displaced person bears the winter cold in a camp in Kabul, Afghanistan.

Credit: DRC/Eric Gerstner, January 2013.

Published by the Internal Displacement Monitoring Centre

Chemin de Balexert 7-9

$\mathrm{CH}-1219$ Châtelaine (Geneva)

Switzerland

Tel: +4122 7990700 / Fax: +41227990701

www.internal-displacement.org and the Norwegian Refugee Council PO Box 6758 St. Olavs plass 0130 Oslo, Norway Tel: +4723109800 Fax: +472310 9801 www.nrc.no

This publication was printed on paper from sustainably managed forests. 


\section{Table of contents}

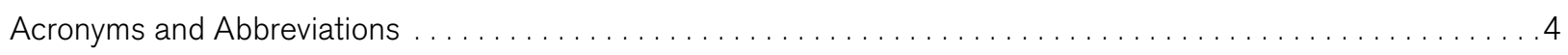

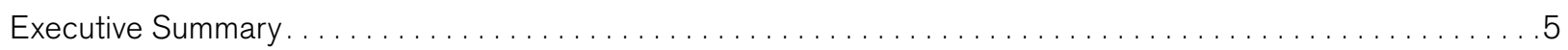

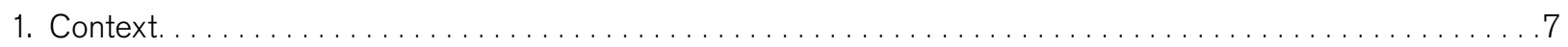

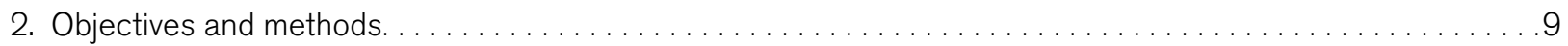

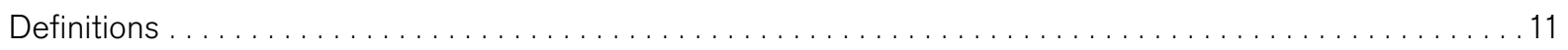

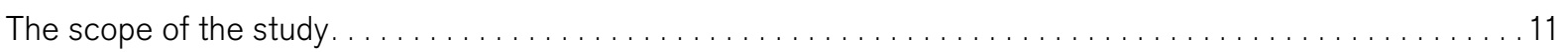

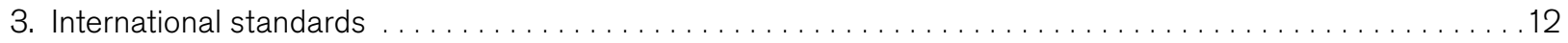

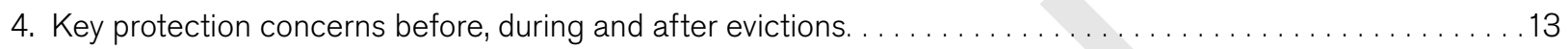

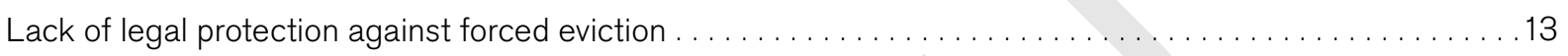

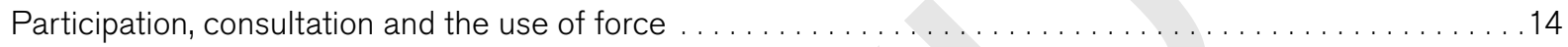

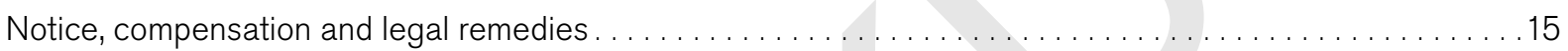

Relocation options and access to adequate housing following eviction . . . . . . . . . . . . . .

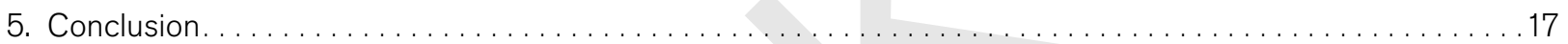

6. Recommendations ................................................ 19

Annex: Case studies . . . . . . . . . . . . . . . . . . . . . . . . . . . . . 21

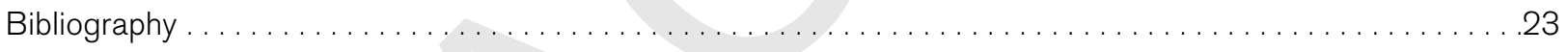

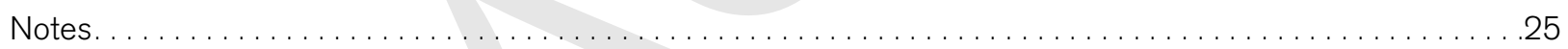




\section{Acronyms and Abbreviations}

Afs

AlHCR

ANDS

ANP

ANSF

Arazi

AREU

CESCR

DoRR

GoA

HLP

HLP TF

$\mathrm{HRC}$

ICCPR

ICESCR

ICLA

ICRC

IDP

IDLG

IDMC

ISAF

KIS

LAS

LEL

LML

MAIL

MoF

MolA

MoRR

MUDA

NATO

NGO

NRC

$\mathrm{OCHA}$

$\mathrm{OHCHR}$

UN

UNDP

UN-HABITAT

UNHCR
Afghan Afghani

Afghan Independent Human Rights Commission

Afghanistan National Development Strategy

Afghan National Police

Afghan National Security Forces

Afghanistan Independent Land Authority

Afghanistan Research and Evaluation Unit

Committee on Economic, Social and Cultural Rights

Department of Refugees and Repatriation

Government of Afghanistan

Housing, Land and Property

Housing, Land and Property Task Force

Human Rights Committee

International Covenant on Civil and Political Rights

International Covenant on Economic, Social and Cultural Rights

Information Counselling and Legal Assistance

International Committee of the Red Cross

Internally Displaced Person

Independent Directorate of Local Governance

Internal Displacement Monitoring Centre

International Security Assistance Force

Kabul Informal Settlements

Land Allocation Scheme

Land Expropriation Law

Land Management Law

Ministry of Agriculture, Irrigation and Livestock

Ministry of Finance

Ministry of Interior Affairs

Ministry of Refugees and Repatriation

Ministry of Urban Development Affairs

North Atlantic Treaty Organisation

Non-Governmental Organisation

Norwegian Refugee Council

United Nations Office for the Coordination of Humanitarian Affairs

Office of the High Commissioner for Human Rights

United Nations

United Nations Development Programme

United Nations Human Settlements Programme

United Nations High Commissioner for Refugees 


\section{Executive Summary}

Some 630,000 Afghans are currently estimated to be internally displaced by ongoing armed conflict and Afghanistan still struggles with the reintegration of over 5.7 million former refugees. 30 per cent of Afghans now live in towns and cities, the majority in informal settlements located in or around the major cities of Kabul, Herat, Mazar-e-Sharif, Jalalabad and Kandahar. Rapid urban growth has been fuelled by the repatriation of refugees, the arrival of IDPs fleeing conflict and disasters as well as economic migration from rural areas. As Afghanistan faces an unpredictable future, achieving durable solutions for the country's internally displaced and refugee-returnee populations remains inextricably linked to delivering housing, land and property (HLP) rights.

This report reviews cases of actual and threatened evictions of IDPs and refugee returnees from informal settlements in and around all the major Afghan cities where the Norwegian Refugee Council has an established field presence. Its main message is the urgent need to ensure legal security of tenure for urban IDPs and refugee returnees, based on a better understanding of Afghanistan's complex urban dynamics. Poverty, informality and marginalisation are a reality for the majority of urban dwellers in Afghanistan and much of the wider urban poor also lack access to adequate housing and secure tenure.

\section{Protection gaps before, during and after evictions}

Forced evictions or threats of evictions affected 9,600 families in the cases documented. Both recently-arrived and longer-term residents are at risk. Lacking affordable housing options, vulnerable internally displaced and returnee families across Afghanistan occupy private and public land without permission. This exposes them to sub-standard living conditions and the constant risk of forced eviction as private landowners and government authorities seek to remove those living without authorisation in order to build public housing, roads, government offices, parks or private housing.

The report highlights the numerous protection gaps encountered before, during and after eviction and makes recommendations to help prevent forced evictions and ensure security of tenure. Major gaps in required practice include:
- absence of clear legal standards on eviction under existing national law

- disregard for rights to consultation and participation of IDPs and returnees facing evictions

- inadequate and widely varying notice periods and procedures

- lack of legal remedies and compensation

- above all, failure to put in place workable relocation options to prevent homelessness and increased vulnerability after eviction.

\section{Policy shortcomings}

The arrival of large numbers of IDPs and refugee returnees in Afghanistan's cities presents the government and the international community with both a protection and an urban development challenge. Informal settlements in Afghanistan can make up entire neighbourhoods. Some are now several decades old. Informal settlements are frequently characterised by insecure tenure, poor sanitation, lack of safe drinking water, high vulnerability to disasters and lack of investment in services and infrastructure.

The pace of urbanisation calls for new systems of land governance, particularly the regulation of informal settlements. However, the authorities have been reluctant to acknowledge informal settlements. The situation is compounded for the displaced whose right to choose their place of settlement has not been recognised. IDPs rarely wish to leave towns and cities where they are living, yet policy-makers fail to acknowledge the mobility of the Afghan population and continue to link long-term solutions to returning 'home.' The primary relocation option presented to IDPs and returnees who face eviction from public or private land is via the Land Allocation Scheme (LAS). However researchers found very limited evidence of successful sustainable relocation to LAS sites.

In addition, key government agencies as well as municipal authorities have viewed solutions for the urban displaced as the responsibility of the Ministry of Refugees and Repatriation. Responses to the needs of the urban displaced have therefore not been well coordinated across government. Implementation of HLP rights also requires a comprehensive response from the government's international humanitarian and development partners. 


\section{Welcome, but insufficient, progress}

Where public or private land and property is occupied without permission, forced evictions are not inevitable. Afghanistan's 2004 Constitution guarantees a number of HLP rights relevant to the prohibition on forced evictions. In 2012, the Afghanistan Protection Cluster's Housing Land and Property Task Force drafted Guidelines for Mitigating Harm and Suffering in Situations of Forced Evictions. A landmark National Policy on Internal Displacement (IDP Policy), adopted by the Afghan Cabinet in November 2013, has since incorporated the Guidelines. The IDP policy:

- recognises the right of IDPs and refugee returnees to adequate housing in urban areas

- contains precise provisions related to forced evictions and security of tenure

- recognises the growth of informal settlements

- recognises IDPs' right under the Afghan Constitution to settle in any part of the country

- acknowledges the responsibility of national, provincial, district and municipal authorities to ensure IDPs and refugee-returnees in informal settlements and other areas are not subject to, or threatened with, forced evictions.

The government's draft Policy on Upgrading of Informal Settlements also provides for protection from forced eviction. However, adoption of the policy was pending at the end of January 2014. Despite many good initiatives by individual agencies, there is still a need for strengthened coordination between development and humanitarian agencies to bridge gaps in international response for IDPs and refugee returnees.

Based on the findings, the Government of Afghanistan, with support of the international community, should:

- take immediate steps to implement the IDP Policy

- introduce comprehensive, effective and coherent laws, policies and plans to prevent and sanction forced evictions of urban IDPs, refugee returnees and the broader urban poor

- institutionalise genuine consultation and participation of affected communities, together with humanitarian and development agencies assisting them

- introduce measures to provide legal security of tenure to vulnerable urban IDPs, returnees and others with no legal access to land and housing

- swiftly adopt the Policy on Upgrading of Informal Settlements and take immediate measures towards implementation
International humanitarian and development partners and donors should:

- adequately and sustainably fund and otherwise support implementation of the IDP Policy

- ensure adequate focus on durable solutions for the displaced in the UN Development Assistance Framework 2015-2019 (UNDAF)

- implement the UN Secretary's General's Framework on Ending Displacement in the Aftermath of Conflict

- encourage joint participation of international development and humanitarian actors in coordination mechanisms addressing internal displacement

- improve capacity of protection actors for preventative monitoring and reporting of evictions and relocations across the country

- ensure consistent funding for capacity building and awareness-raising activities on forced evictions. 


\section{Context}

Afghans face a critical period of political and security transition. Presidential elections are scheduled for April 2014 and the Afghan National Security Forces (ANSF) have taken over lead responsibility for security from the NATO-led International Security Assistance Force (ISAF). According to the Office of the United Nations High Commissioner for Refugees (UNHCR), 630,000 Afghans are currently estimated to be internally displaced by the ongoing armed conflict. ${ }^{1}$ Afghanistan continues to struggle with the reintegration of over 5.7 million former refugees who have repatriated from Iran and Pakistan since 2002.

As the country faces an unpredictable future, achieving durable solutions for Afghanistan's internally displaced and refugee-returnee populations remains inextricably linked to delivering housing, land and property (HLP) rights. Past destruction of homes, state facilities and infrastructure, rural landlessness and the illegal occupation of land and property still pose major obstacles. ${ }^{2}$ Today, rapid urbanisation, the resulting dramatic rise in urban land prices and expansion of informal settlements present further challenges in accessing adequate housing and basic services. ${ }^{3}$ An observation on Afghanistan made a decade ago by the former UN Special Rapporteur on the Right to Adequate Housing remains pertinent: finding a "balance between development priorities and the housing, land and property rights" is necessary to guard against forced eviction. ${ }^{4}$
Up to 30 per cent of Afghans now live in towns and cities and urban population growth is well above averages elsewhere in Asia. Kabul's population alone has doubled from two million in 2001 to 4.5 million in 2010 and is projected to reach an estimated six million by $2020 .{ }^{5}$ Urban growth has been fuelled by repatriation of refugees, the arrival of IDPs fleeing conflict and disasters and economic migration from rural areas. UNHCR reports that an estimated 15 per cent of refugee-returnees are reported to later become migrants. ${ }^{6}$ Of those who migrate internally, the great majority move from rural to urban areas. Some 40 per cent of IDPs are estimated to live in urban areas. ${ }^{7}$ Urban IDPs are even less likely than those in rural areas to wish to return to their place of origin. ${ }^{8}$

As in many countries, urban IDPs often live alongside the wider urban poor and experience similar challenges. ${ }^{9}$ Indeed, three quarters of Afghans affected by conflict have faced some form of displacement and in cities such as Kabul most of the urban poor have been IDPs or refugees at some point in their lives. ${ }^{10}$ Poverty, informality and marginalisation are a reality for the majority of urban dwellers in Afghanistan and much of the wider urban poor lack access to adequate housing and secure tenure. ${ }^{11}$

Roughly 60-70 per cent of urban areas in Afghanistan have developed informally. ${ }^{12}$ The majority of informal settlements are located in or around the major cities

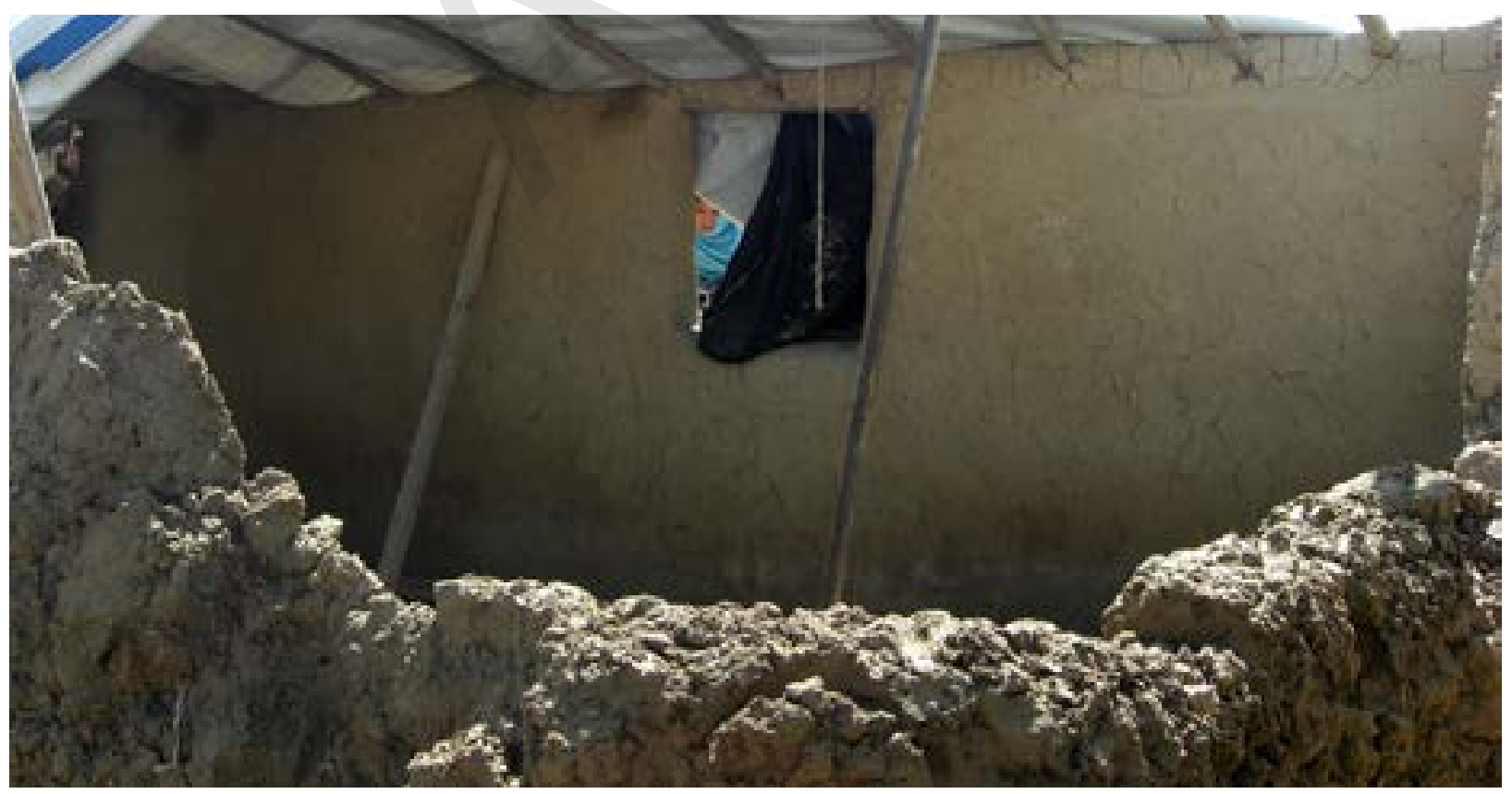

This housing in Nasaji Bagrami was reportedly damaged after heavy rains (IDMC/Caroline Howard, March 2013). 
of Kabul, Herat, Mazar-e-Sharif, Jalalabad and Kandahar. Informal settlements are frequently characterised by weak security of tenure, poor sanitation, lack of access to drinking water, high vulnerability to disasters and lack of investment in services and infrastructure. ${ }^{13}$ They include diverse categories of tenure with varying degrees of formal recognition. ${ }^{14}$ In Kabul, where 70 per cent of the population lives in informal settlements, ${ }^{15}$ many residents have customary deeds. Roughly 33,000 people also occupy over 50 informal sites with no form of authorisation from the land-owner (the so-called Kabul Informal Settlements or KIS).

Informal areas can make up entire neighbourhoods or be dispersed throughout richer areas. They are found on government, municipal and private land. Although some are now several decades old, and house a protracted IDP caseload, many others have been established more recently. Afghans who legally acquire land may choose not to undertake procedures to formalise ownership. Realisation of internationally-acknowledged housing land and property (HLP) rights in Afghanistan is greatly complicated by the reality that most people do not have the land documentation required under current national law to prove ownership. ${ }^{16}$

In 2012, the Afghanistan Protection Cluster's Housing Land and Property Task Force (HLP TF) ${ }^{17}$ drafted and disseminated Guidelines for Mitigating Harm and Suffering in Situations of Forced Evictions. ${ }^{18}$ They are intended to "orient and influence" national authorities on how to develop a "coherent eviction and relocation policy" that prevents the forced eviction of IDPs, refugee-returnees and other conflict-affected civilians who occupy land in urban areas without the owner's permission. Based on international human rights standards, the Guidelines are also generally applicable to urban residents.
A landmark National Policy on Internal Displacement (IDP Policy), adopted by the Afghan Cabinet on 28 November 2013, has since incorporated the Guidelines. ${ }^{19}$ Significantly, the IDP Policy recognises the right of IDPs and refugee returnees to adequate housing in urban areas and also contains precise provisions related to forced evictions and security of tenure. Among other provisions of the policy, relevant authorities are required to:

- review existing legislation to ensure effective legal protection against forced evictions, prior to, during and after an eviction, with special focus on the vulnerable

- introduce adequate temporary or permanent land and housing schemes to ensure IDPs' security of tenure, including by renting, leasing or usufruct arrangement

- legalise informal settlements and improve land titling to ensure IDPs' security of tenure, thus enabling shelter improvements and helping achieve durable solutions. ${ }^{20}$ 


\section{Objectives and methods}

Based on a review of cases of actual or threatened evictions documented by the Norwegian Refugee Council (NRC) and its Internal Displacement Monitoring Centre (IDMC), this report aims to highlight the numerous protection gaps encountered by urban IDPs and refugee-returnees before, during and after eviction. It also explores some of the obstacles to improving security of tenure in urban areas. There are concrete recommendations on how government and international humanitarian and development actors might help to prevent future forced evictions.
The report presents evidence from 16 informal settlements in and around all the major Afghan cities where NRC has an established field presence: Kabul (six cases), Herat (three cases), Nangahar (four cases) and one each in Mazar-e-Sharif, the town of Maimana in Faryab province and from Farah in south-west Afghanistan. The first was recorded in November 2010 and the last in June 2013. Each involved multiple affected families, as illustrated below:

\begin{tabular}{|c|c|c|c|c|c|c|}
\hline No & $\begin{array}{l}\text { Informal } \\
\text { settlement }\end{array}$ & $\begin{array}{l}\text { Urban } \\
\text { centre }\end{array}$ & $\begin{array}{l}\text { Threat of } \\
\text { eviction / } \\
\text { forced eviction }\end{array}$ & $\begin{array}{l}\text { Affected } \\
\text { families }\end{array}$ & $\begin{array}{l}\text { IDP / refugee } \\
\text { returnee/ urban } \\
\text { poor }\end{array}$ & Type of land \\
\hline 1 & Yakatoot & Kabul & Forced eviction & 26 & IDPs & Private \\
\hline 2 & $\begin{array}{l}\text { Tapa-e-Nasaji } \\
\text { Bagrami }\end{array}$ & Kabul & Threat & 90 & $\begin{array}{l}\text { IDPs/wider urban } \\
\text { poor }\end{array}$ & $\begin{array}{l}\text { Public (Ministry of Finance - MoF) } \\
\text { (contested by private actor) }\end{array}$ \\
\hline 3 & Nassaji Bagrami & Kabul & Threat & 270 & $\begin{array}{l}\text { IDPs/refugee } \\
\text { returnees }\end{array}$ & $\begin{array}{l}\text { Public (MoF) (contested by private } \\
\text { actor) }\end{array}$ \\
\hline 4 & Tapa-e-Qasaba & Kabul & Threat & 300 & IDPs/urban poor & Private \\
\hline 5 & Charahi Qambar & Kabul & Threat & 900 & $\begin{array}{l}\text { IDPs/refugee } \\
\text { returnees }\end{array}$ & Public (Ministry of Defence - MoD) \\
\hline 6 & Chaman-e-Usrui & Kabul & Threat & 200 & $\begin{array}{l}\text { IDPs/refugee } \\
\text { returnees/urban } \\
\text { poor }\end{array}$ & $\begin{array}{l}\text { Public (National Olympic } \\
\text { Committee) }\end{array}$ \\
\hline 7 & $\begin{array}{l}\text { Ferdawsi } \\
\text { Intersection* }\end{array}$ & $\begin{array}{l}\text { Mazar-e- } \\
\text { Sharif }\end{array}$ & Forced eviction & 27 & Protracted IDPs & $\begin{array}{l}\text { Communal (contested by } \\
\text { municipality) }\end{array}$ \\
\hline 8 & Tatar Khana* & Maimana & Threat & 13 & Protracted IDPs & Communal \\
\hline 9 & Maslach & Herat & Threat & 3,000 & Protracted IDPs & Public \\
\hline 10 & Shaidayee & Herat & Threat & 1,800 & Protracted IDPs & Public (municipal) \\
\hline 11 & Minaret & Herat & Threat & 190 & $\begin{array}{l}\text { Protracted IDPs/ } \\
\text { refugee returnees }\end{array}$ & $\begin{array}{l}\text { Contested between MoD and } \\
\text { private actor }\end{array}$ \\
\hline 12 & Mekaniza & Farah & Forced eviction & 214 & $\begin{array}{l}\text { IDPs/ refugee } \\
\text { returnees }\end{array}$ & $\begin{array}{l}\text { Public (Ministry of Agriculture, } \\
\text { Irrigation and Livestock - MAIL) }\end{array}$ \\
\hline 13 & Farmiada* $^{*}$ & Jalalabad & Forced eviction & 190 & Refugee returnees & Public (MAIL) \\
\hline 14 & Abdul Haq Park & Jalalabad & Threat & 46 & Refugee returnees & Public (municipal) \\
\hline 15 & Siasang Village & Jalalabad & $\begin{array}{l}\text { Forced eviction } \\
\text { and threat }\end{array}$ & $\begin{array}{l}700(100 \\
\text { evicted })\end{array}$ & Refugee returnee & Public \\
\hline 16 & $\begin{array}{l}\text { Hisarshahi/ } \\
\text { Kabul camp }\end{array}$ & Jalalabad & Threat & 1,600 & Protracted IDPs & Public (municipal) \\
\hline
\end{tabular}

* For a summary of these cases, please see annex. 


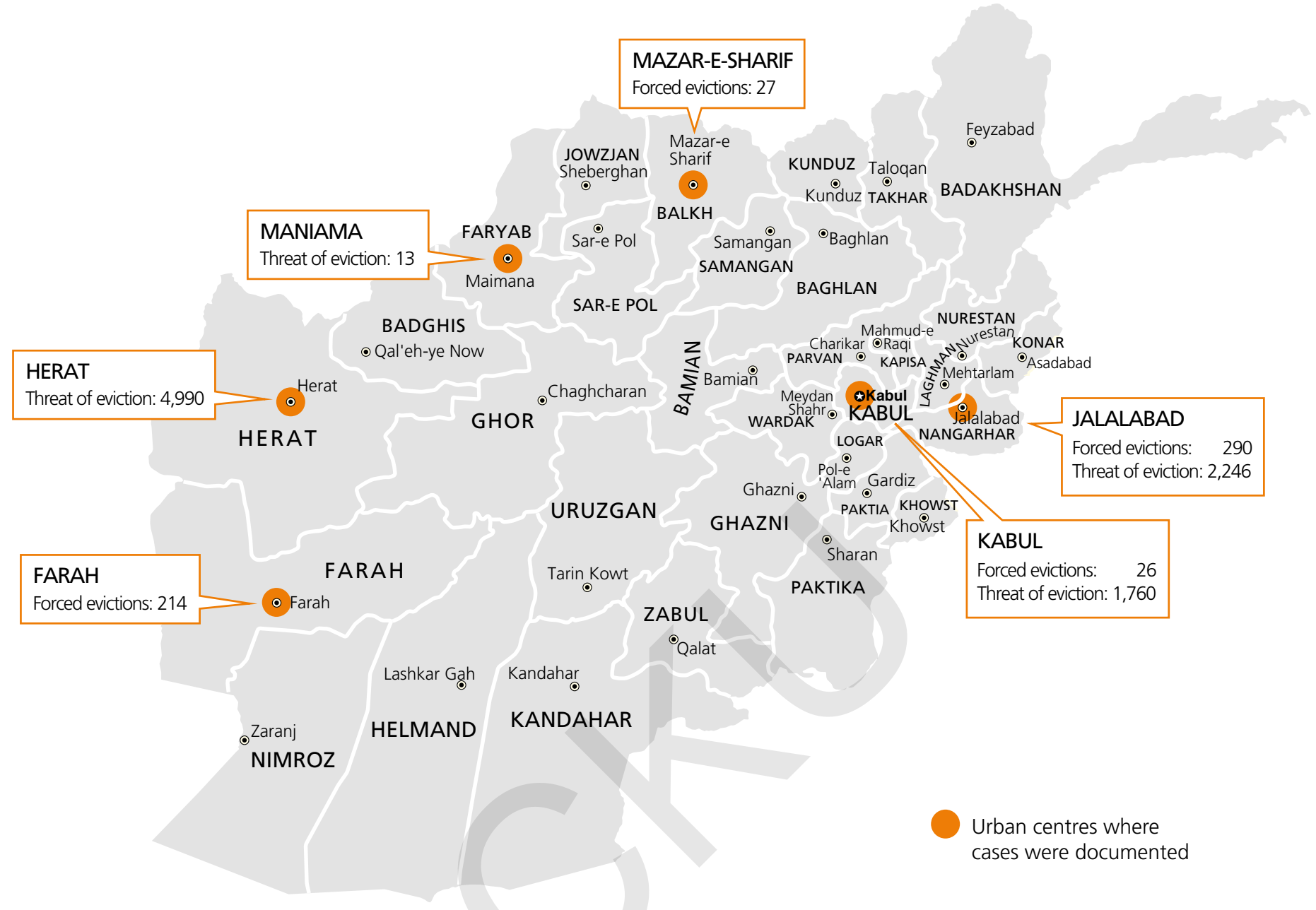

Approximately 9,6oo families (57,400 individuals) are estimated to be affected by threats of eviction, including 557 families actually subject to forced evictions. As NRC provides humanitarian assistance to refugees, internally displaced persons (IDPs) and returnees, ${ }^{21}$ research focused on settlements where IDPs and refugee-returnees were affected. Some of these sites also housed other urban poor, including those from nomadic communities and migrants from rural areas.

In Kabul, residents facing eviction in the sampled communities had lived at the settlement in question for an average of four years, while in other parts of the country those facing eviction have occupied land for an average of 11 years.

Nine cases involved public land reportedly owned by a government authority and two cases involved private land. In two cases, several families with customary title also faced eviction. Ownership could not be determined in three cases as the land occupied by IDPs and returnees was disputed by private and government actors.
Information was primarily gathered by NRC during community visits and interviews with community representatives and staff of international non-governmental organisations (INGOs), UN humanitarian and development agencies and the Afghan Independent Human Rights Commission (AIHRC). ${ }^{22}$ Municipalities, provincial offices of the Department of Refugees and Repatriation (DoRR) and governors' offices were consulted wherever possible. A questionnaire was distributed to field staff.

IDMC also conducted missions to Kabul in March and October 2013 which involved interviews with members of the HLP TF, other land and housing specialists, IDPs and refugee-returnees in two informal settlements in Kabul where families had occupied land without the land-owner's permission. We also interviewed the Deputy Minister of Urban Development Affairs (MUDA) and the General Director of the General Directorate of Municipal Affairs of the Internal Directorate of Local Governance (GDMA/ IDLG) and reviewed key national legislation, policies and selected secondary literature. 


\section{Definitions}

The term "forced evictions" is defined by the Committee on Economic, Social and Cultural Rights (CESCR) as:

the permanent or temporary removal against their will of individuals, families and/or communities from the homes and/or land which they occupy, without the provision of, and access to, appropriate forms of legal or other protection. ${ }^{23}$

An "IDP" is defined in line with the UN Guiding Principles on Internal Displacement as:

persons or groups of persons who have been forced or obliged to flee or to leave their homes or places of habitual residence, in particular as a result of or in other to avoid the effects of armed conflict, situations of generalized violence, violations or human rights or natural and human-made disasters, and who have not crossed an internationally recognised border. ${ }^{24}$

A "returnee" is "every person who returns to Afghanistan after he or she was compelled to leave the country due to persecution or a situation of generalised violence, including returning asylum seekers and refugees." 25

This report adopts UN-HABITAT's broad definition of "informal settlement", which includes:

(i) residential areas where a group of housing units has been constructed on land to which the occupants have no legal claim, or which they occupy illegally; (ii) unplanned settlements and areas where housing is not in compliance with current planning and building regulations (unauthorised housing). 26

Tenure is understood as "the set of relations with respect to housing and land established through statutory law or customary, informal or hybrid arrangements" and security of tenure as "tenure of land and/or housing which ensures a secure home and enables one to live in security, peace and dignity." ${ }^{27}$ As the CESCR notes, "tenure takes a variety of forms including rental agreements, leases, owner occupation, emergency housing and informal settlements." 28

\section{The scope of the study}

This report reviews the protection challenges faced by urban IDPs and returnees during evictions in Afghanistan and make recommendations to prevent forced evictions in urban areas. It is beyond its scope to comprehensively review the many complex land tenure issues and urban development challenges which influence tenure security and thus shape the practice of forced eviction. Neither can it assess the various initiatives launched by government and non-government actors in the last ten years to address these challenges.

Given the focus of cases documented on IDPs and returnees, this report does not attempt to draw conclusions as to whether IDPs are more exposed to forced eviction than the wider urban poor. In order to deepen understanding of displacement-specific vulnerabilities and needs and improve responses, improved IDP profiling is needed in urban areas across Afghanistan.

While this paper focuses on the plight of IDPs and returnees in urban and semi-urban areas, forced evictions also occur in rural areas where they are driven by ongoing armed conflict, land acquisition for large-scale rural development projects and conflict over land rights. An NRC/IDMC IDP protection study conducted in 2012 found evictions to be "marginally more present in urban and peri-urban areas than rural areas." Further research is recommended to map similarities and differences between evictions that take place in rural and urban contexts. ${ }^{29}$ 


\section{International standards}

Forced evictions are a serious violation of a range of internationally recognised human rights and an important barrier to achieving long-term solutions for IDPs and refugee-returnees. In many instances, they are also a cause or primary or secondary displacement. ${ }^{30}$

Protection analysis in this report is grounded on Afghanistan's obligations under international human rights law. In particular, as a party to the International Covenant on Economic, Social and Cultural Rights (ICESCR), Afghanistan is legally bound to ensure that all persons enjoy at least basic elements of the right to adequate housing, including "a degree of security of tenure which guarantees legal protection against forced eviction." ${ }^{31}$ Furthermore, as a party to the International Covenant on Civil and Political Rights (ICCPR), the country is obliged to respect the right to privacy against unlawful or arbitrary interference with personal and family life, including home ${ }^{32}$, irrespective of the legality of the residence. The Convention on the Elimination of Discrimination against Women (CEDAW) ${ }^{33}$ and the Convention on the Rights of the Child $(C R C)^{34}$ to which Afghanistan is a party also provide further formal protection against forced eviction.

International law is clear that evictions should only take place in exceptional circumstances, such as to reclaim occupied public land, following non-payment of rent or in order to restore land rights of legitimate private land owners. In these circumstances, authorities must ensure that evictions are always carried out in accordance with both domestic legislation and relevant international human rights standards. Afghanistan is required to refrain from carrying out forced evictions and ensure that the law is enforced against third parties who carry them out. ${ }^{35}$

International human rights law requires:

- consultation and participation of affected people and communities on alternatives to eviction and, if eviction is unavoidable, on relocation options

- adequate and reasonable notice of forthcoming eviction

- effective legal remedies and compensation for those affected by evictions orders, whether or not they hold legal title to their homes or have other forms of tenure

- legal use of force to always be necessary and proportionate

- prohibition of actions resulting in homelessness and deteriorated housing and living conditions. ${ }^{36}$
Consulting and involving people affected by evictions can help to identify alternative to evictions, avoid violence and increase the chances of any relocation succeeding. International standards require authorities to provide residents with relevant information and ensure that they are able to participate during the different stages of an eviction. ${ }^{37}$

Individuals, or their legal representatives, must be given the opportunity to challenge eviction decisions. If an eviction is unavoidable, fair compensation must also be provided for any losses of personal property, including rights in property, irrespective of whether formal title is held. Where land has been taken, those evicted should be compensated with land commensurate in quality, size and value, or better. ${ }^{38}$

To the maximum extent possible with available resources Afghan authorities must ensure that all appropriate measures are taken to provide adequate alternative housing, resettlement or access to land "if those affected are unable to provide for themselves." ${ }^{39}$ Like other states, Afghanistan is further obliged to adopt "appropriate strategies, policies and programmes" to ensure effective protection against forced evictions and their consequences..$^{40}$ The international community has a clear role to play assisting the Afghan authorities to promote HLP rights. ${ }^{41}$ 


\section{Key protection concerns before, during and after evictions}

IDPs and refugee returnees occupying government and privately owned land with no form of authorisation face eviction to make way for urban development and infrastructure projects such as public housing, road-building, government offices, parks, and private housing developments. Both recently-arrived and longer-term residents are at risk. Protection concerns are reported at every stage of eviction. This study identifies major gaps in required practice including:

- the absence of clear legal standards on eviction under existing national law

- disregard for rights to consultation and participation of IDPs and returnees facing evictions

- inadequate and widely varying notice periods and procedures

- lack of legal remedies and compensation

Arguably most serious is the failure to put in place workable relocation options to prevent homelessness and increased vulnerability after eviction.

\section{Lack of legal protection against forced evic- tion}

Afghanistan's 2004 Constitution guarantees a number of rights to housing, land and property relevant to the prohibition on forced evictions. ${ }^{42}$ Under article $40(4)$, "nobody's property shall be confiscated without the provisions of law and the order of an authorized court." Article 38 further provides that, "no one, including the state, shall have the right to enter a personal residence [...] without the owner's permission or by order of an authoritative court, except in situations and methods delineated by law." 43 Article 14 requires that "the state shall adopt necessary measures for provision of housing and distribution of public estates to deserving citizens in accordance with the provisions of law and within financial possibilities." 44 However, none of the evictions planned or carried out in the studied communities had been authorised by a court order.

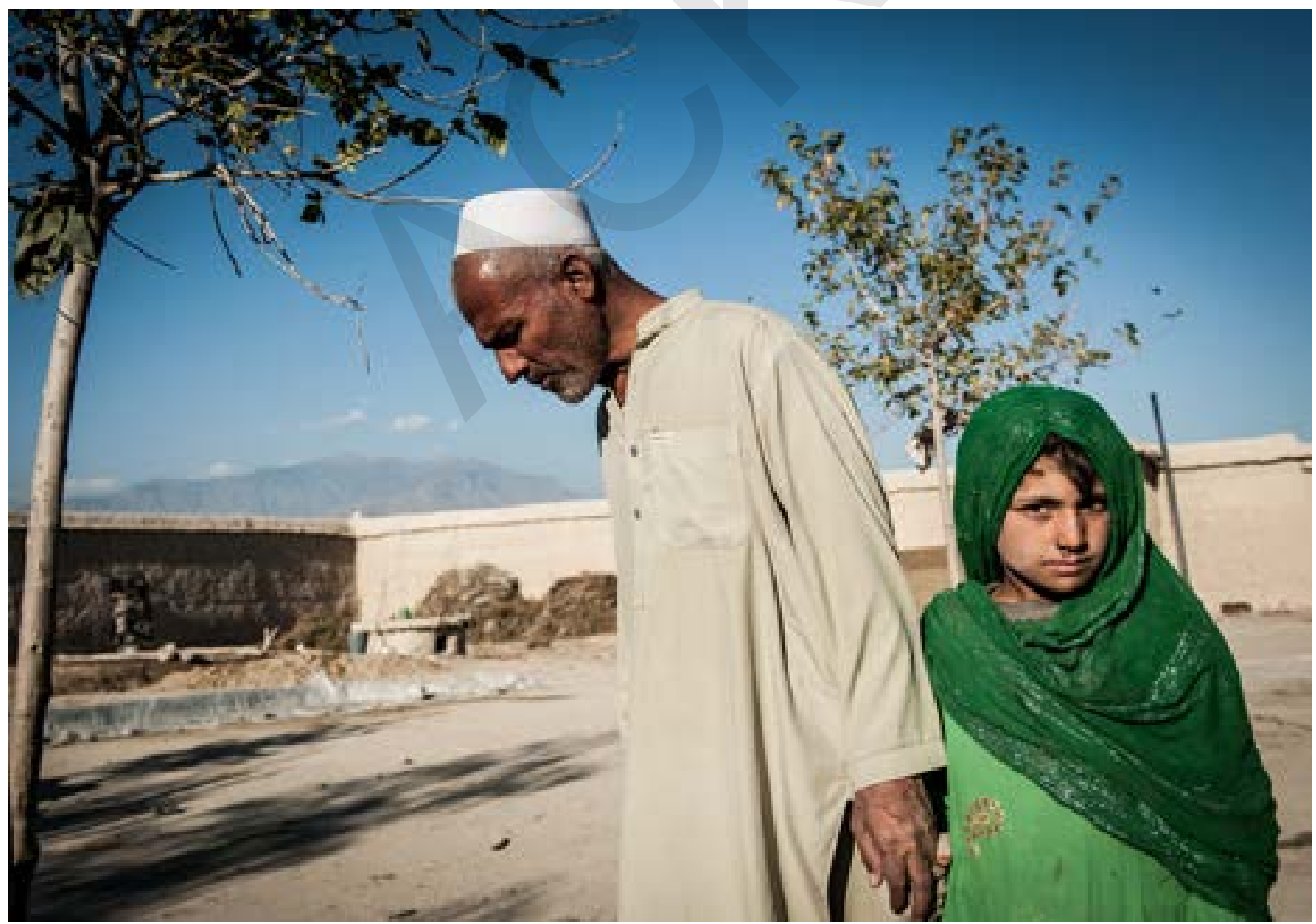

IDPs in Laghman province (NRC/Christian Jepsen, November 2013). 
While there are a number of relevant Constitutional protections, Afghanistan's national law is silent on eviction procedures for those occupying land without permission and circumstances under which eviction of such residents is permitted. Shari'ah, as the base of Afghan national law ${ }^{45}$ and a reference point in case of silence of statutory law, seem to have not developed effective safeguards against arbitrary expropriations and forced evictions, though there are norms with arguably limited direct applicability. ${ }^{46}$ According to the Committee on Economic, Social and Cultural Rights, legislation against forced eviction should:

include measures which a) provide the greatest possible security of tenure to occupiers of houses and land; b) conform to the [ICESCR]; c) are designed to strictly control the circumstances under which evictions may be carried out [and are also] adequate to prevent and if appropriate punish forced evictions carried out without appropriate safeguards by private persons or bodies. ${ }^{47}$

Amended in 2005 and 2010, the 2000 Land Expropriation Law (LEL) regulates government expropriation of private property for public purposes, so is not applicable to families who do not own property or live on occupied public land. On paper, the LEL makes limited provision for compensation (in the form of cash or alternative land) and also for three-month's notice for those evicted. However, the payment of compensation is not required if the land expropriated is not privately owned or deemed to belong to the state. ${ }^{48}$ In addition, there is no legal requirement for the government to relocate affected individuals to alternative sites and no right of appeal against an eviction decision. Amendment of the LEL was ongoing as of January 2014.

Afghanistan's main land law, the 2008 Land Management Law (LML), also fails to provide sufficient protection against forced eviction. Articles 21 and 22 of LML, in relation to a limited number of others, provide only general rules pertaining to expropriation of private land owned by an individual. Afghanistan's civil land administration, the Afghanistan Independent Land Authority (Arazi) has been amending the LML since 2011. Amendments submitted to the Ministry of Justice in late 2012 do not include any significant additional protection, save for a couple of post-facto protection clauses. For example, the newly proposed Article 42(1)(i) prioritises land distribution for landless people whose "under cultivation and work land has been possessed and expropriated by the state for the sake of public interests." The draft Article 107 introduces an option of "re-housing" for affected land-owners. No option of compensation is available. ${ }^{49}$ In addition, the draft law has "weak or no positive measures to address tenure insecurities endured by women, sharecroppers,
IDPs and returnees forced to occupy public lands for a lack of alternative lands." 50

The draft Policy on Upgrading of Informal Settlements ${ }^{51}$ provides for drafting of legislation to prevent unlawful or arbitrary evictions. However, adoption of the policy was pending as of January 2014.

As long as public confidence in the statutory justice system remains low any legislative amendments will be unlikely to directly benefit IDPs and returnees. Moreover, new legislation does not protect against forced evictions in every case. For example, the broadly defined draft Law on Grabbing and Illegal Occupation of State-Owned and Private Property (Land-grabbing Law), which seeks to prevent and sanction the illegal grabbing of private and public land by powerful individuals, could be construed as permitting forced evictions and sanctioning the criminal prosecution of vulnerable groups such as IDPs and returnees who occupy high-value state-owned land. ${ }^{52}$

\section{Participation, consultation and the use of force}

Evictions are organised with little if any genuine dialogue between the government and those occupying land. In roughly half of all cases, residents knew an eviction had been planned, but were not consulted or involved in any discussion on alternatives to evictions or relocation options. Too often, this leaves IDPs and returnees uncertain of the time-frame for their eviction and their future. Consultations with IDPs and returnees only tend to take place after a private land-owner or state authority has decided to evict them. Discussions are generally limited and do not propose alternatives. Most often, those involved are a community representative from the settlement and an official from the local Department of Refugees and Repatriations (DoRR), although there is rarely one clear government interlocutor tasked to lead discussions.

The primary relocation option presented to IDPs and returnees who face eviction by the authorities is to apply for land under the government's Land Allocation Scheme (LAS). Created in 2005 under Presidential Decree number 104, LAS aims to facilitate the reintegration and return of landless IDPs and refugee returnees through the distribution of intact and uncultivated public land in provinces of origin. ${ }^{53}$ However, most IDPs do not wish to return to their place of origin and prefer to remain where they are, or stay close by, citing livelihoods opportunities, access to services and security as reasons. ${ }^{54}$ This view is rarely appreciated or accommodated by the authorities.

LAS sites are also generally located far from livelihood opportunities, with no access to basic infrastructure and 
services. Additionally, the eligibility criteria exclude IDPs and returnees who lack documents while relatively high land fees and procedural deficiencies associated with LAS pose a significant barrier for the most vulnerable. ${ }^{55}$

Given the lack of genuine consultation, some IDPs and returnees petition their Provincial Council or provincial governor to halt their evictions. Others try and use ethnic ties or other connections. In two cases, IDPs also sought advice from NRC.

During evictions, provincial or municipal authorities may call for assistance from NGOs or the UN, although rarely with a view to finding an alternative to the eviction itself. Through mechanisms such as the Afghanistan Protection Cluster (APC) and its national and regional Housing Land and Property task-forces - which have been established to coordinate humanitarian protection responses, including on land and property issues - humanitarian agencies and human rights organisations are sometimes able to positively influence the planning and execution of evictions. They have called on authorities not to carry out evictions during winter, refrain from excessive force, put in place adequate relocation plans and generally adhere to all other provisions within the Forced Evictions Guidelines. Humanitarian agencies may also step in to provide emergency food or shelter after evictions and to advocate with the MoRR or other authorities to find appropriate relocation options. This largely hinges on whether an agency has field access and sufficient capacity.

Along with the private or government land owner involved, the Afghan National Police (ANP) is normally present at the time of eviction. Violence and arrests are rarely reported, but do occur. In May 2012 at Farmiada settlement, south of Jalalabad, a child was fatally injured and nine returnees arrested when protests started as ANP and MAIL officials started to demolish homes with bulldozers, after having given two day's notice. ${ }^{56}$ In the Yakatoot settlement in Kabul in August 2012, the ANP reportedly arrested seven IDPs at the request of a private land-owner who had accused them of "land-grabbing" after they occupied his land without permission. Police allegedly imprisoned the IDPs for some six months until all inhabitants at the site agreed to leave. The landowner subsequently paid the affected families compensation.

\section{Notice, compensation and legal remedies}

Irrespective of whether or not they hold legally valid ownership documentation, all vulnerable groups have a right to basic procedural protections against forced evictions. However, as noted above, where public or private land has been occupied without permission current Afghan legislation offers no guidance on key procedural issues such as notice prior to eviction, legal remedies or provision of compensation.

Eviction rarely takes place without residents receiving any form of notification at all. However, the notice given is always inadequate, with no jurisdictional or procedural clarity on the authority tasked with issuing eviction notices. No written eviction notice is normally provided. Typically, a representative from the private landowner or relevant government authority will visit a settlement and inform a community representative the residents must leave. They provide no clear time-frame, explanation of the eviction decision or information on alternative housing or other assistance. Visits may continue sporadically over a number of years with little further detail being provided, leaving communities highly uncertain as to their future.

With insufficient information and no viable and affordable alternative housing options available, IDPs and returnees are often unwilling or unable to leave their homes. In one case reported in Farah, authorities had informed residents of their intention to evict them on several occasions over the previous two years, but families had still not left their homes. Authorities and police then finally evicted the families with less than 48 hours warning in freezing cold weather in November 2012. The state provides no compensation for loss of property or physical injuries caused by eviction, although private landowners do reportedly make ad hoc financial arrangements with affected communities in some instances.

In August 2012, in the Tatar Khana area of Maimana town, a number of protracted IDPs with customary deeds to their homes approached the Faryab governor after municipal authorities attempted to evict them for a second time. Suspecting that the road construction plans which threatened their homes had been altered due to improper influence exerted by a local power-broker, the IDPs complained and the provincial governor established an investigatory panel. It found in favour of the IDPs and the eviction was suspended. However, a final decision was pending with MUDA in Kabul at the end of 2013. ${ }^{57}$

\section{Relocation options and access to adequate housing following eviction}

International standards require the Afghan government to do all it can to ensure vulnerable IDP and returnee families are not made homeless or forced to live in worse housing conditions as a result of eviction. Nonetheless, very few of those at risk of eviction are presented with real alternative housing options.

Relocation to a LAS site was proposed in nine of the 16 cases reported, and is the authorities' preferred solution 
for IDPs and returnees. Some families at risk of eviction are willing to apply for land under the scheme despite having to pay. Eligibility criteria established for the LAS are problematic. Following eviction of over 190 refugee returnee families from the Farmiada informal settlement in Behsud district of Nangahar province in May 2012, the local DoRR office did not consider those originating from neighbouring Kunar province as eligible to apply for LAS plots in Nangahar. Returnees from Kunar were advised instead to return to Kunar and apply there, even though they did not wish to do so due to ongoing armed conflict. There is no coherent government position on the eligibility of IDPs under the scheme. In Mazar e-Sharif and Farah, IDPs originating from other provinces who are at risk of eviction have been considered eligible to apply for LAS land. In Kabul province however, this is not the case.

IDPs and returnees often view LAS sites as being less suitable than the informal settlements where they have chosen to reside. Across the country, those who are encouraged to relocate to LAS land express numerous reservations. These include the cost of applying, the distance of LAS sites from urban centres currently providing livelihood opportunities, inadequate living conditions at the sites proposed and lack of access to drinking water, housing and basic services.

NRC documented no case in which there had been successful relocation to a LAS site. In Farah and Jalalabad, IDP and returnee families who reported having applied and paid for LAS plots had waited for many months to be allocated land, but not received it. As a result, they either re-occupied public land, or continued living where they had been when evicted but in even more precarious types of shelter. For example, 46 returnee families facing eviction from the Abdul Haq informal site outside Jalalabad city, where a new park is planned, reported that they applied for LAS land in November 2011 but in August 2013 were still on a waiting list. Eviction was imminent but no other alternative had been suggested.

When relocation of informal settlers is proposed there is little or no effective coordination between key government and municipal authorities. Municipal and other government land holders as well as representatives of MUDA typically view the provision of housing solutions for IDPs and returnees as the exclusive responsibility of MoRR. At the Mechaniza informal settlement in Farah city the provincial office of DoRR had been unable to complete allocation of LAS plots to over 200 IDP and returnee families facing eviction from land held by MAIL, despite requests by the provincial governor for several years to do so. Although relocation had not been a success the provincial governor declined to further delay their eviction and the families' homes were demolished during cold winter weather in November 2012. According to community representatives, the families had been unwilling to leave Mechaniza as the LAS site proposed was unaffordable, incomplete and located too far from current livelihoods.

Land-owners occasionally seek other ad hoc solutions for those they wish to evict. However, these generally fail to materialise and do not provide security of tenure or protection against further eviction. At the Charahi Qambar settlement in Kabul a private company renting land from the MoD offered 14 IDP families cash compensation if they would move to make way for a petrol station. The families accepted and in April 2013 moved to another part of the same site. The government has proposed no option to address the long term needs of the 900 families living on the site except relocation to a LAS site for those eligible. IDPs say that they are not willing to return to their provinces in southern Afghanistan due to the ongoing conflict.

With no relocation policy in place and no effective coordination between the key government and municipal actors, forced evictions result in homelessness and heightened vulnerability for IDPs and returnees. Following the Yakatoot eviction, for example, some residents moved to tents in a desert area on the outskirts of Kabul, some to other districts villages and others to informal settlements inside the city. Emergency food and shelter is rarely made available for those evicted, although in some cases the government does request humanitarian agencies to provide emergency assistance. Evicted communities may eventually find more permanent shelter for themselves. However, lack of secure tenure remains a constant challenge and the risk of further eviction and secondary displacement is ever present. 


\section{5}

\section{Conclusion}

The arrival of large numbers of IDPs and refugee returnees in Afghanistan's cities presents the government and the international community with both a protection and an urban development challenge. Lacking affordable housing options, vulnerable internally displaced and returnee families occupy private and public land without permission across Afghanistan which exposes them to precarious living conditions and a constant risk of forced eviction.

Domestic law fails to establish the clear legal standards on eviction or the procedural protections required by the Afghan Constitution and the state's international human rights obligations. Evictions are planned and carried out with no genuine consultation, inadequate notice, no due process and without compensation. In the vast majority of cases, evicted IDP and returnee families have no prospect of being relocated to adequate alternative housing by either the government or private land-owners. No relocation policy is in place. This results in a series of protection risks and prevents them from achieving long-term solutions.
Where public or private land and property is occupied without permission, forced evictions are not inevitable..$^{58}$ Over the last decade, a number of initiatives by government and non-government actors have directly or indirectly sought to strengthen security of tenure and increase access to adequate housing for urban dwellers. ${ }^{59}$ These include programmes to upgrade and legalise informal settlements, land titling initiatives, legislative and policy reforms and programmes to reform and develop the capacity of land management institutions such as Arazi. Although procedures to legalise land ownership have been simplified, land titling remains expensive and inaccessible to all but a few.

Although there have been limited positive changes, the state has insufficiently addressed issues around urban security of tenure. Appropriate legislation and land and housing policies are required to guarantee tenure security and urban development plans must take into account the needs and rights of the poorest and most vulnerable. Widespread land-grabbing for private gain by strongmen,

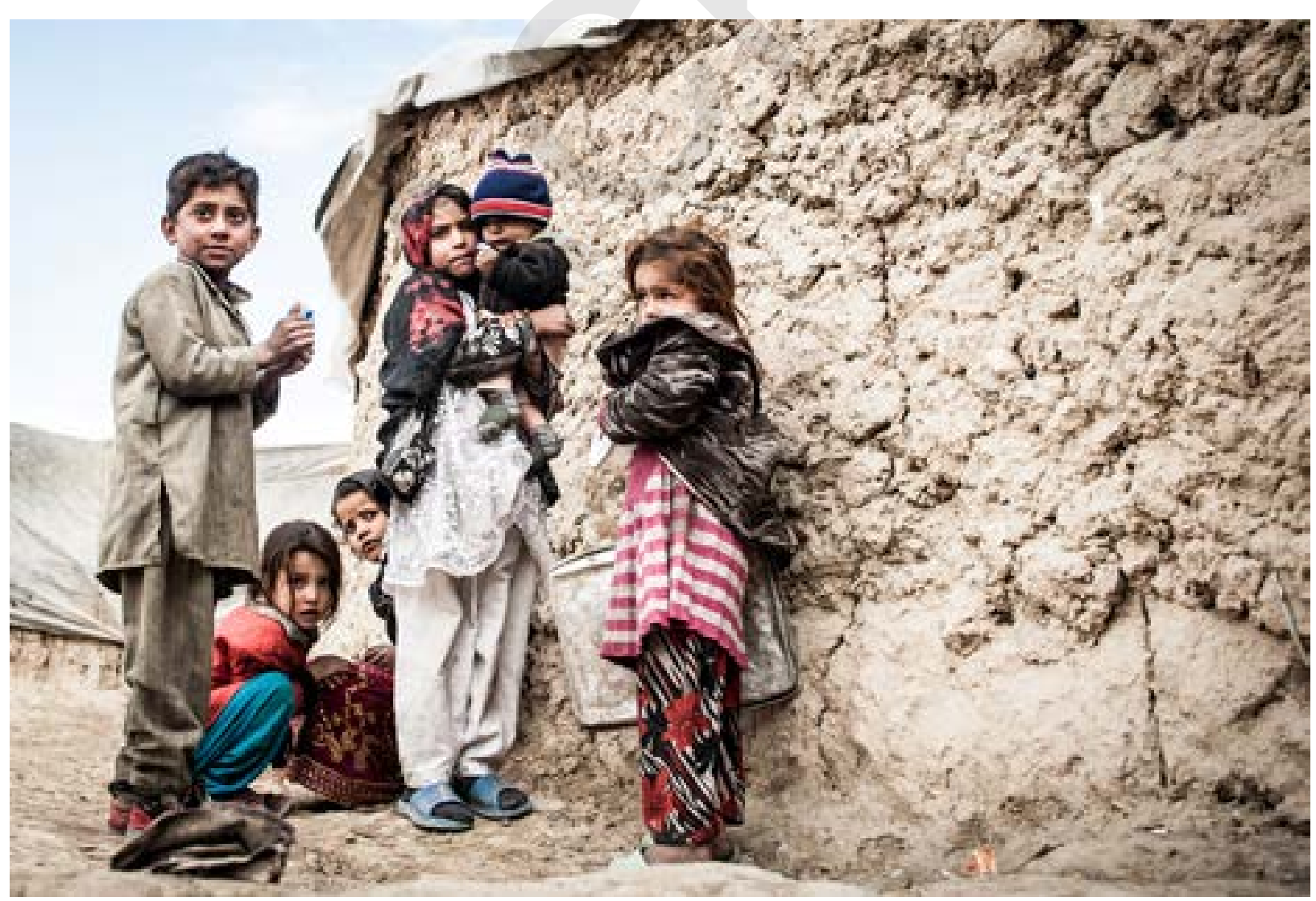

Internally displaced children in Kabul (NRC/Christian Jepsen, November 2013). 
government officials and other powerful individuals remains a crucial barrier to provision of adequate housing in rural and urban areas. Legislation and effective enforcement is much needed to counter impunity. However, the draft Law on Grabbing and Illegal Occupation of State-Owned and Private Property could be construed as permitting forced evictions and sanctioning the criminal prosecution of vulnerable groups such as IDPs and returnees who occupy high-value public land.

The pace of urbanisation necessitates new systems of land governance, particularly the regulation of informal settlements. However, development of policies relating to legalisation of informal settlements has been "hesitant".60 Authorities have been reluctant to acknowledge informal settlements, insisting they are only temporary and must be demolished. ${ }^{61}$ Overlapping roles and responsibilities within government, insufficient resources and weak urban governance structures have further impeded efforts towards regulation.

The perception that upgrading and legalisation of informal settlements will encourage further rural-urban migration has presented a major challenge to the adequate settlement of the urban poor. The situation is compounded for IDPs whose right to choose their place of settlement has not been recognised. IDPs' rarely wish to leave towns and cities where they are living, yet Afghan authorities have clearly linked long-term solutions to their return "home". The Afghan National Development Strategy 62 (ANDS) for 2008-2013 provided a basic framework for the protection of IDPs, but did not set out measures to achieve durable solutions other than return.

Key government agencies such as MUDA, MRRD as well as municipal authorities have largely viewed solutions for the urban displaced as the responsibility of MoRR and responses to the urban displaced have not been coordinated. The LAS remains the principal relocation option available.

There are welcome signs, however, that official attitudes are shifting. Consensus is also emerging that informal settlements should be upgraded and legalised, rather than demolished. Afghanistan's first National IDP Policy recognises the growth of informal settlements and acknowledges the responsibility of national, provincial, district and municipal authorities to ensure that IDPs and refugee-returnees in informal settlements and other areas are not subject to, or threatened with, forced evictions. The government's 2013 draft Policy on Upgrading of Informal Settlements is highly welcome. ${ }^{63}$ Sufficient resources and political will are likely to present key challenges to implementation however.
Implementation of HLP rights also necessitates a comprehensive response from humanitarian and development partners. Housing and land have long been recognised as "cross cutting issues of direct and indirect concern to all UN actors." 64 Despite many good initiatives by individual agencies, there is a need for strengthened coordination between development and humanitarian agencies to bridge gaps in international response. Community-based programmes involving both displaced and non-displaced urban populations are likely to lead to more effective long-term solutions for IDPs and refugee returnees. ${ }^{65}$ A better understanding of Afghanistan's complex urban dynamics, as well as the specific needs of urban IDPs and returnees, is critical. 


\section{Recommendations}

\section{The Government of Afghanistan should, with international support:}

- take immediate steps to implement the National IDP Policy, through timely development of national and provincial action plans on durable solutions and improved profiling of IDPs' specific needs in relation to urban housing, land and property

- introduce comprehensive, effective and coherent laws, policies and plans to prevent and sanction forced evictions of urban IDPs, refugee returnees and the broader urban poor, as to, at minimum:

- clarify precise conditions and procedures under which evictions of settlers occupying public and private land in urban areas can be carried out and ensure the legality, necessity and proportionality of such evictions

- ensure jurisdictional and procedural clarity concerning the government authority responsible for issuing eviction notices

- provide adequate and reasonable notice to those at risk of eviction in a standardised written format

- prohibit the use of excessive force during evictions, including the destruction of housing as a form of pressure

- provide adequate government-assisted relocation/ rehousing options with available sufficient infrastructure and public utilities

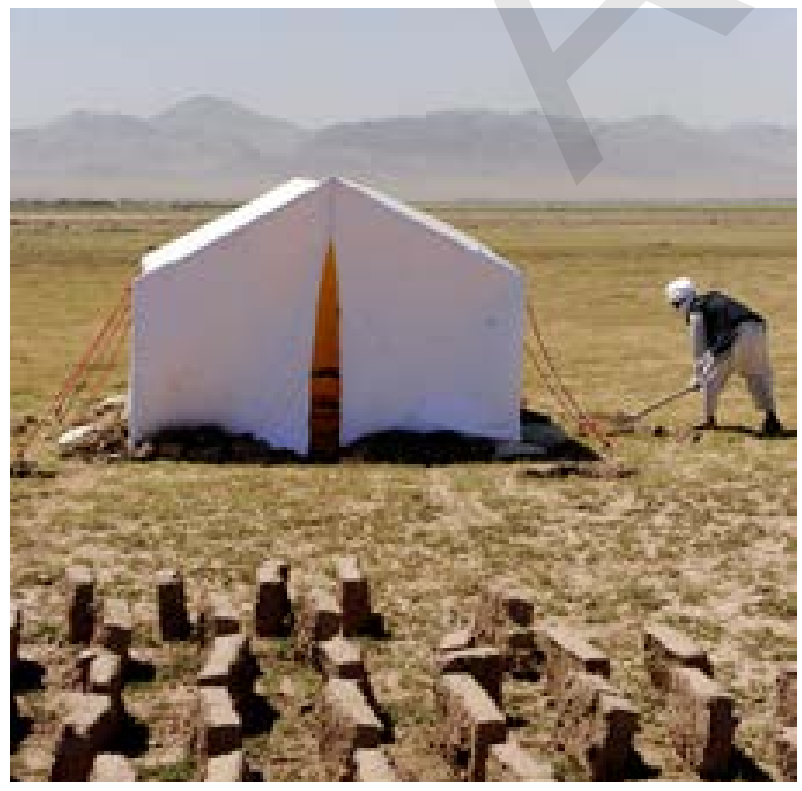

A displaced man puts up his tent in a Emergency Response camp in Herat province of Afghanistan. Photo: NRC/Warzana Fahidy, June 2012.
- provide compensation mechanisms meeting international standards, including methods to assess losses incurred as a result of evictions taking into account the individual's tenure status

- introduce effective administrative and judicial appeal/review against flawed eviction decisions, implementation and compensation determination

- ensure effective prosecution of individuals and institutions of authority initiating and conducting unlawful evictions

- ensure new laws do not serve to undermine legal protection against forced eviction or sanction the prosecution of vulnerable groups such as IDPs and returnees who occupy public land.

- institutionalise genuine consultation and participation of affected communities, together with humanitarian and development agencies assisting them, by:

- ensuring all affected individuals, including women and the elderly, are kept duly informed throughout all eviction phases

- ensuring, in particular, timeliness and proper communication of formal evictions notices

- suspending challenged eviction notices until the lawfulness of a decision has been administratively and/or judicially reviewed.

- introduce measures to provide legal security of tenure to vulnerable urban IDPs, returnees and others with no legal access to land and housing, including by:

- imposing a moratorium on all forced evictions until a proper legal framework is adopted.

- expanding informal settlement upgrading and legalisation programmes

- revising Presidential Decree 104 to better address the beneficiaries' needs, with focus on adequate site selection, reduction or exclusion of land fees and broader eligibility criteria inclusive of IDPs and refugee-returnees living outside their province of origin

- exploring other means of ensuring security of tenure beyond private land ownership

- taking practical steps to promote large-scale affordable, low-cost or state-subsidised housing

- improving and prioritising urban land management and administration

- taking into account the specific needs of the poorest, including IDPs and returnees in relevant urban land and housing policies

- ensuring effective coordination between key gov- 
ernment and municipal authorities when relocation of informal settlers is proposed.

- swiftly adopt the Policy on Upgrading of Informal Settlements and take immediate measures towards implementation

\section{The international community (humanitarian and development partners and donors) should:}

- fund and otherwise support implementation of the IDP Policy, including IDP profiling activities on HLP required to deepen understanding of displacement-specific needs and improve responses

- ensure the UN Development Assistance Framework 2015-2019 (UNDAF) adequately focuses on durable solutions for IDPs and refugee returnees, including realisation of the right to adequate housing in urban areas through community-based programmes
- implement the 2011 UN Secretary's General's Framework on Ending Displacement in the Aftermath of Conflict, with equal attention paid to both IDPs and refugee returnees

- encourage international development actors to effectively support and participate alongside humanitarian actors in the National IDP Task Force, HLP Task Force and other relevant coordination mechanisms so as to ensure a comprehensive approach to displacement in urban areas

- improve capacity of protection actors for preventative monitoring and reporting of evictions and relocations across the country, with view to helping find alternatives to evictions

- ensure consistent funding for capacity building and awareness-raising activities on forced evictions and applicable (international) legal standards for all stakeholders. 


\section{Annex: Case studies}

\section{Farmiada case, Nangarhar province}

One hundred and ninety refugee families (1,051 individuals) returned from Pakistan after their houses in Zakhil refugee camp were destroyed in the 2010 floods. More than half (113 families) are originally from Kunar where the ongoing conflict renders return impossible, while the rest are from Nangahar. They were squatting in Farmiada, a semi-urban area of Behsud district, Nangahar province, located around $3 \mathrm{~km}$ to the south of Jalalabad city. No other families were settled there.

Immediately upon return from Pakistan in late August 2010, the families were squatting in an olive farm for two weeks. Upon Police request to leave, they moved to the land owned by the MAIL (Valley Development Department - Canal Department) after being granted the temporary permission to stay there.

The families were evicted on 17 May 2012, reportedly at the request of the Provincial Governor, after being given only 48-hours oral notice without any prior consultations. According to UNHCR, DoRR, AIHRC and the families, the Canal Department and the Afghan National Police (ANP) carried out the eviction using bulldozers and tractors. During house demolitions, ANP exerted unnecessary force and detained for 24 hours 9 individuals who resisted the demolition (released after AlHRC intervened). A child died of injuries sustained in the demolition (when the surrounding wall collapsed) and families were left homeless and without any compensation.

The HLP Task Force intervened and the DoRR agreed to temporarily relocate returnees to Chamtala Township (LAS) in Khogyani district. All returnee families from Nangahar were promised permanent plots in Chamtala. However, families from Kunar were told to return to their homes and referred to their provincial DoRR (based on a provision of the Decree 104). As the families were highly vulnerable, NRC and other NGOs provided emergency assistance. As of 2013, none of the families have received their plots (according to NRC 100,000 LAS applications have been pending in Nangahar).

Unable to construct permanent shelters in Chamtala for many months, families originating from both Kunar and Nangarhar moved to Salozay, a rural area of Chaparahar district, outside Jalalabad. They purchased land from a person claiming to be the land owner who had promised to provide customary deeds for the land once full payment would be received. In June 2013, a joint needs assessment was conducted at the site by humanitarian agencies including NRC, UNHCR, IRC and Save the Children. Shelter, potable water, education, health and employment were identifies as main problem areas faced by the families. As of August 2013, NRC built 158 one-room shelters for the most vulnerable families and DACAAR dug 2 wells (hand pump). Other NGOs are yet to conduct their activities in the area.

The families have been in debt and still have to pay installments for the land they purchased. It is unclear if the land seller is the actual owner as there are no land registries for the area. Thus, the families remain at risk of eviction.

\section{Ferdawsi Intersection case, Balkh province}

Twenty seven families of internally displaced persons from Kotak village of Balkh district, were living for 20 years in Ferdawsi intersection, District 7, a formal part of Mazar city. They lived on disputed land - municipal authorities claimed to own it, while the families asserted their rights on the grounds of customary deeds, after purchasing the land 15 years before from a local commander ruling the area. The IDPs are casual laborers with children attending school in Mazar.

The families were evicted on 18 November 2011, based on a decision of municipal Construction Department and the Provincial Governor's Office to construct a new road in line with the 2011 Mazar Master Plan. No court order was issued due to the alleged governmental/public ownership of the land.

Upon being requested to leave, the families petitioned the Provincial Council on a couple of occasions, with no specific feedback received. As the families did not hold a recognized legal title to the property (the commander they bought the land from could not have been legally considered the owner to transfer the land rights), there was no possibility of recourse to statutory legal remedy. After the initial request, the Municipality Department showed no further interest in the case until September 2011 when they visited the families and again requested them to leave. Two weeks later, on 3 October 2011, the municipality gave the final 48 -hour eviction notice. On the same day, the families once again petitioned a special "community dispute resolution" department within Provincial Council, which ruled that the families had to be 
evicted but within an extended eviction notice period of 15 days. Nevertheless, on 5 October 2011, the municipal authorities bulldozed the families' homes without resorting to violence. No relocation site was offered and the IDPs rented houses or moved in with relatives in Mazar City and the vicinity (Ishani, Ammani sub-districts).

In December 2012, the families requested compensation from DoRR which referred them to NRC for legal aid. As the claimants had no formally recognized title deeds, the municipality was not legally obliged to provide alternative land or compensation. However, considering the IDP status of the families, the mayor agreed to provide them plots of public land in the new Do Raie Hairatan (LAS) township, conditional upon consent from MUDA and payment of a fee. The families have been concerned about the fact that the township is located far away $(17 \mathrm{~km})$ from Mazar, with no infrastructure and services available (no potable water, sanitation, schools, health clinics etc.) rendering the site an inadequate substitute for their lost land. At the same time, the full procedure for allocating/ receiving the land plots is expected to be lengthy, further prolonging their displacement. In March 2013, the approval of the municipal project in the township was granted and the mayor promised to start the land distribution as soon as the project is finished. So far, the municipal project has been ongoing and the plight of the families continues.

\section{Tatar Khana case, Faryab province}

Thirteen protracted IDP families (77 persons) have lived in the semi-urban Tatar Khana area of Maimana city in Faryab. The IDPs fled from their places of origin four years ago due to conflict. Five families are from Mouqani village of Pashtunkot district, five families from Qalai Naw city of Badgis province and three families from Qaisar district. The IDPs have tried to find work as casual labourers but are mainly unemployed, while their children attend Maimana schools in the area. Families hold customary deeds to their land, having purchased the land from private owners when it was still considered agricultural, rather than residential.

Following a decision of the municipality to construct a road in line with the Maimana City Master Plan, some 30 families had already been evicted from the area in 2010. No notice was given or alternative housing offered. The families lost their land, education and livelihood opportunities and were forced into secondary displacement. In August 2012, the 13 families more were notified that their evictions were planned due to further road construction. Without prior consultation, a municipal representative in charge of land allocation verbally notified the families about the ongoing development project, and requested them to move out.
The risk of eviction was the result of a controversial change in the initial MUDA Master Plan which had originally foreseen a different route for the road construction. The change was reportedly introduced under the influence of local powerbrokers who did not want their own property destroyed. As the IDPs have not held formal land title deeds, no court order was considered mandatory (although a court order should have been issued for the original private owner of the land). Again, no relocation or compensation plan has been proposed.

The community referred the case to the Provincial Governor's Office which established a panel to clarify the reasons for changes of the original plans. In March 2013, the panel concluded that the map was illegally revised and this reportedly led to temporary suspension of the construction. The case has been pending with MUDA and it remains unclear if the construction works will proceed and which route will be chosen. The families remain under the eviction risk.

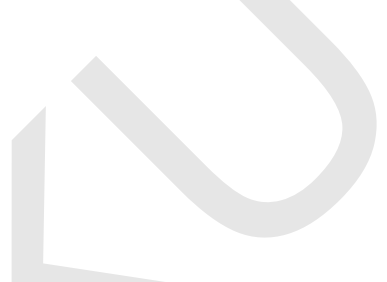




\section{Bibliography}

Afghan Independent Human Rights Commission (AlHRC), 2011, Fifth Report on the Situation of Economic and Social Rights in Afghanistan, http://www.aihrc.org.af/media/ files/Reports/SECR/Report\%200n\%20ESCR_Final_ English_12_2011.pdf

Afghanistan Protection Cluster, Housing Land and Property Task Force (HLP TF), 2012, Guidelines for Mitigating Harm and Suffering in Situations of Forced Eviction, http://www.globalprotectioncluster.org/ assets/files/field_protection_clusters/Afghanistan/ files/HLP\%20AoR/Guidelines_For_Mitigating_Harm_ in_Forced_Evictions_Afghanistan_2012_EN.pdf

Aga Khan Trust for Culture, 2011, Kabul urbanisation and development challenges: A synthesis report, http:// acku-koha-photos.osslabs.biz/cgi-bin/koha/opac-detail. pl?biblionumber $=20812$

Committee on Economic, Social and Cultural Rights (CECSR), 2010, Consideration of reports submitted by States parties under articles 16 and 17 of the Covenant: Concluding observations of the Committee on Economic, Social and Cultural Rights - Afghanistan, E/C.12/AFG/ CO/2-4, http://www.refworld.org/docid/4ef1fb5e2.html

Committee on Economic, Social and Cultural Rights (CESCR), General Comment No. 4: The Right to Adequate Housing (art. 11.1 of the Covenant) (Sixth session, 1991), U.N. Doc. E/1992/23, http://www.refworld.org/ docid/47a7079a1.html

Committee on Economic, Social and Cultural Rights (CESCR), General Comment 7, The right to adequate housing (art 11.1 of the Covenant) and forced evictions (Sixteenth session, 1997), U.N. Doc. E/1998/22, http://www.unhchr.ch/tbs/doc.nsf/\%28symbol\%29/ CESCR+General+Comment+7.En?OpenDocument.

Human Rights Committee (HRC), 1988, General Comment 16 (Twenty-third session), U.N. Doc. HRI/GEN/1/Rev.1 (1994), http://www1.umn.edu/humanrts/gencomm/hrcom16.htm

Ingrid Macdonald, 2011, Landlessness and Insecurity: Obstacles to Reintegration in Afghanistan, Middle East Institute - Foundation pour la Recherche Strategique (MEI-FRS), http://www.refugeecooperation.org/ publications/Afghanistan/04_macdonald.php
Internal Displacement Monitoring Centre (IDMC), 2013, Afghanistan: Comprehensive response urgently required as displacement crisis worsens, http://www.internal-displacement.org/8025708 Foo4CEgoB/\%28httpCountries\%29/DFADB5842Fg262BF 802570A7004BA6Fo?OpenDocument

International Committee of the Red Cross (ICRC), 2009, Opinion Survey and In-Depth Research, http://www. icrc.org/eng/assets/files/2011/afghanistan-opinionsurvey-2009.pdf

Islamic Republic of Afghanistan, 2004, The Constitution of Afghanistan http://www.afghanembassy.com.pl/afg/ images/pliki/TheConstitution.pdf.

Islamic Republic of Afghanistan, 2008, Afghanistan National Development Strategy, 1387-1391 (2008-2013), http://www.undp.org.af/publications/KeyDocuments/ ANDS_Full_Eng.pdf

Islamic Republic of Afghanistan, 2013, The National Policy of the Islamic Republic of Afghanistan on Internal Displacement, http://morr.gov.af/en/page/8102

Islamic Republic of Afghanistan, July 2013, Policy on Upgrading of Informal Settlements in Afghanistan, http://www.idlg.gov.af/eng/GDMA Miloon Kothari, 2004, Adequate housing as a component of the right to an adequate standard of living. Report by the Special Rapporteur, Miloon Kothari, Addendum, Mission to Afghanistan (31 August-13 September 2003), http://www. refworld.org/docid/409100130.html

Miloon Kothari, 2007, Report of the Special Rapporteur on adequate housing as a component of the right to an adequate standard of living, Annex 1 (A/HRC/4/18), Basic principles and guidelines on development-based evictions and displacement, http://daccess-dds-ny. un.org/doc/UNDOC/GEN/G07/106/28/PDF/G0710628. pdf?OpenElement

Liz Alden Wily, 2012, Land Governance at the Crossroads: A review of Afghanistan's Proposed New Land Management Law, Afghanistan Research and Evaluation Unit (AREU), http://www.areu.org.af/EditionDetails.aspx? Editionld $=600 \&$ Contentld $=7 \&$ Parentld $=7 \&$ Lang $=e n-U S$ 
Liz Alden Wily, 2013, Land, People, and the State in Afghanistan: 2002-2012, Afghanistan Research and Evaluation Unit (AREU), http://www.areu.org.af/Uploads/ EditionPdfs $/ 1303$ E $\% 20$ Land $\% 2011 \% 20$ C S $\% 20$ Feb $\% 20$ 2013.pdf

Victoria Metcalfe, Simone Haysom, with Ellen Martin, 2012, Sanctuary in the City: Urban displacement and Vulnerability in Kabul, Humanitarian Policy Group/ Overseas Development Institute (HPG/ODI), http://www. odi.org.uk/sites/odi.org.uk/files/odi-assets/publicationsopinion-files/7722.pdf

Norwegian Refugee Council (NRC) Afghanistan, March 2010, Guidance Note on Presidential Decree 104, unpublished, on file with NRC/IDMC

President of the Islamic Republic of Afghanistan, 2005, Decree on Land Distribution for Housing to Eligible Returnees and IDPs - No. 104, http://morr.gov. af/Content/Media/Documents/Presidentialdecree 104218201110421115553325325.pdf

Samuel Hall/NRC/IDMC/Joint IDP Profiling Service, 2012, Challenges of IDP Protection: Research Study on the protection of internally displaced persons in Afghanistan, http://www.internal-displacement. org/8025708Fo04BE3B1/(httplnfoFiles)/D7EC12FE714 A55EgC1257AC5004D8D7C/\$file/challenges-of-idpprotection-afghanistan-2012.pdf

UN General Assembly, 1966, International Covenant on Economic, Social and Cultural Rights (ICESCR). http:// www.ohchr.org/EN/Professionallnterest/Pages/CESCR. $\underline{\text { aspx }}$

UN General Assembly, 1979, Convention on the Elimination of All Forms of Discrimination against Women, http:// www.un.org/womenwatch/daw/cedaw/cedaw.htm

UN General Assembly, 1989, Convention on the Rights of the Child, http://www.ohchr.org/en/professionalinterest/ pages/crc.aspx

UN Guiding Principles on Internal Displacement, 1998, http://www.ohchr.org/EN/Issues/IDPersons/Pages/ Standards.aspx

UN High Commissioner for Refugees (UNHCR) and World Bank, 2011, Research study on IDPs in urban settings Afghanistan, http://www-wds.worldbank.org/ external/default/WDSContentServer/WDSP/IB/20 12/05/07/000333037_20120507005841/Rendered/ PDF/68539oWPOoPUBLoPsoinourbanosettings.pdf
UN High Commissioner for Refugees (UNHCR), 2012, International Conference on the Solutions Strategy for Afghan Refugees to Support Voluntary Repatriation, Sustainable Reintegration and Assistance to Host Countries, http://www.unhcr.org/4fa7eoeag.html

UN Office for the Coordination of Humanitarian Affairs (OCHA), 2013, Afghanistan: Humanitarian Needs Overview 2014, https://afg.humanitarianresponse.info/system/ files/documents/files/Afg_2014HNO_FINALV2_0.pdf

UN Office for the Coordination of Humanitarian Affairs (OCHA), December 2013, Humanitarian Bulletin Afghanistan - Issue 23, 01-31 December 2013, https:// afg.humanitarianresponse.info/system/files/documents/ files/MHB\%20Dec_v6_o.pdf

UN Secretary General's Policy Committee, 2011, UN Secretary General's Decision on Ending Displacement in the Aftermath of Conflict - Decision No 2011/20, 4 October 2011, http://www.internal-displacement .org/8025708Fo04CFA06/(httpKeyDocumentsBy Category)/D3152FA6C910768EC125799500425ABB/ $\$$ file/UN\%2oframework\%20ending\%20displacement.pdf 


\section{Notes}

1. OCHA, Humanitarian Bulletin Afghanistan - Issue 23, 01-31 December 2013, December 2013, pp. 1-2, https://afg.humanitarianresponse.info/system/files/ documents/files/MHB\%20Dec_v6_o.pdf

2. Miloon Kothari, 2004, Adequate housing as a component of the right to an adequate standard of living. Report by the Special Rapporteur, Miloon Kothari, Addendum, Mission to Afghanistan (31 August-13 September 2003), pp.7-8, p.14, pp.22-23 http://www.refworld.org/docid/409100130.html

3. UN Committee on Economic, Social and Cultural Rights (CESCR), 2010, Consideration of reports submitted by States parties under articles 16 and 17 of the Covenant: Concluding observations of the Committee on Economic, Social and Cultural Rights - Afghanistan, E/C.12/AFG/CO/2-4, para 39: "The Committee is concerned about the forced eviction and demolition of tenements that take place in the State party, without due process of law or sufficient notice and without adequate compensation or alternative accommodation." http://www.refworld. org/docid/4ef1fb5e2.html

4. Kothari, 2004, op. cit., p. 6.

5. Victoria Metcalfe, Simone Haysom, with Ellen Martin, 2012, Sanctuary in the City: Urban displacement and Vulnerability in Kabul, Humanitarian Policy Group/ Overseas Development Institute (HPG/ODI), p.7, http://www.odi.org.uk/sites/odi.org.uk/files/odiassets/publications-opinion-files/7722.pdf

6. UNHCR, 2012, International Conference on the Solutions Strategy for Afghan Refugees to Support Voluntary Repatriation, Sustainable Reintegration and Assistance to Host Countries, p.22, http://www.unhcr. org/4fa7eoeag.html

7. UN Office for the Coordination of Humanitarian Affairs (OCHA), 2013, Afghanistan: Humanitarian Needs Overview 2014, p.10, https://afg.humanitarianresponse. info/system/files/documents/files/Afg_2014HNO_ FINALV2_o.pdf

8. Samuel Hall/NRC/IDMC/Joint IDP Profiling Service (JIPS), Challenges of IDP Protection: Research Study on the protection of internally displaced persons in Afghanistan, November 2012, p.31, p.67, http://www.internal-displacement. org/8025708Fo04BE3B1/(httplnfoFiles)/ D7EC12FE714A55E9C1257AC5004D8D7C/\$file/ challenges-of-idp-protection-afghanistan-2012.pdf p.46, p.49.

9. Metcalfe, op. cit., p.2.

10. International Committee of the Red Cross (ICRC), Opinion Survey and In-Depth Research, June 2009, p.23, http://www.icrc.org/eng/assets/files/2011/ afghanistan-opinion-survey-200g.pdf

11. Aga Khan Trust for Culture, Kabul urbanisation and development challenges: A synthesis report, September 2011, http://acku-koha-photos.osslabs. biz/cgi-bin/koha/opac-detail.pl?biblionumber $=20812$ pp.12-22.

12. UNHCR/World Bank, 2011, Research study on IDPs in urban settings Afghanistan, p.12. http:// www-wds.worldbank.org/external/default/ WDSContentServer/WDSP/IB/2012/05/07 /000333037_20120507005841/Rendered/ PDF/685390WPooPUBLoPsoinourbanosettings.pdf.

13. UNHABITAT Afghanistan, see http://www.unhabitat. org/content.asp? cid $=4.907 \&$ catid $=245 \&$ typeid $=13$ and http://www.unhabitat.org/content.asp?cid= 7793 \& catid $=245 \&$ typeid $=13$

14. Aga Khan Trust, op. cit., pp. 41-46, 52-55.

15. UNHCR/World Bank, 2011, Ibid., p.11.

16. Liz Alden Wily, 2013, Land, People, and the State in Afghanistan: 2002-2012, AREU, p.44. http://www.areu. org.af/Uploads/EditionPdfs/1303E\%20Land\%20 $\underline{\| 1 \% 20 C S \% 20 F e b \% 202013 . p d f}$

17. http://www.globalprotectioncluster.org/assets/ files/field_protection_clusters/Afghanistan/files/ APC_HLP_Task_Force_ToR_EN.pdf

18. http://www.globalprotectioncluster.org/_assets/ files/field_protection_clusters/Afghanistan/files/ HLP\%20AoR/Guidelines_For_Mitigating_Harm in_Forced_Evictions_Afghanistan_2012_EN.pdf; HLP Task Force, Guidelines for Mitigating Harm and Suffering in Situations of Forced Evictions, September 
2012, http://www.globalprotectioncluster.org/ assets/files/field_protection_clusters/Afghanistan/ files/HLP\%20AoR/Guidelines_For_Mitigating _ Harm_in_Forced_Evictions_Afghanistan_2012 EN.pdf

19. See Annex 4 of the National Policy of the Islamic Republic of Afghanistan on Internal Displacement, November 2013, http://morr.gov.af/en/page/8102.

20. Ibid., articles 4.4.1.v, 5.4 (f), 7.1.3.1 (i) and (m), 7.2 (d) iii, 8.4 (e). http://morr.gov.af/en/page/8102.

21. See http://www.nrc.no/?aid=916069o

\section{2. http://www.aihrc.org.af.}

23. Committee on Economic, Social and Cultural Rights (CESCR), General Comment 7, The right to adequate housing (art 11.1 of the Covenant) and forced evictions (Sixteenth session, 1997), U.N. Doc. E/1998/22, para 3 , http://www.unhchr.ch/tbs/doc.nsf/\%28symbol\%2g/ CESCR+General+Comment+7.En?OpenDocument.

24. UN Guiding Principles on Internal Displacement (1998), http://www.ohchr.org/EN/Issues/IDPersons/Pages/ Standards.aspx.

25. Government of Afghanistan, National IDP Policy, p.11.

26. UN-HABITAT, Enabling shelter strategies; Review of experience from two decades of implementation, 2006, p.4. http://ww2.unhabitat.org/programmes/ housingpolicy/documents/HS-785.pdf

27. Raquel Rolnik, 2012, Report of the Special Rapporteur on adequate housing as a component of the right to an adequate standard of living, and on the right to non-discrimination in this context, UN Human Rights Council , A/HRC/22/46, paras. 22-23.

28. UN Committee on Economic, Social and Cultural Rights (CESCR), General Comment No. 4: The Right to Adequate Housing (art. 11.1 of the Covenant) (Sixth session, 1991), U.N. Doc. E/1992/23, para. 8(a), http:// www.refworld.org/docid/47a7079a1.html.

29. Samuel Hall/NRC/IDMC/JIPS, op. cit., p.31, p. 67; and AIHRC, 2011, Fifth Report on the Situation of Economic and Social Rights in Afghanistan, November/December 2011, pp. 62-63, http://www. aihrc.org.af/media/files/Reports/SECR/Report\%20 on\%20ESCR_Final_English_12_2011.pdf;
30. Internal Displacement Monitoring Centre (IDMC), Global Overview 2011: people internally displaced by conflict and violence, April 2012, p.21. http://www. internal-displacement.org/publications/globaloverview-2011.

31. Article 11(1) of the International Covenant on Economic, Social and Cultural Rights (ICESCR) acceded to on 24 January 1983, http://www.ohchr.org/EN/ Professionallnterest/Pages/CESCR.aspx; CESCR, General Comment 4, op. cit., para 8(a).

32. The term "home" under Article 17(1) of the ICCPR indicates "the place where a person resides or carries out his usual occupation". HRC, General Comment 16 (Twenty-third session, 1988), U.N. Doc. HRI/GEN/1/ Rev.1 (1994), para 5, http://www1.umn.edu/humanrts/ gencomm/hrcom16.htm.

33. CEDAW Article 14(2)(h); CRC Article 27(3).

34. http://www.ohchr.org/en/professionalinterest/ pages/crc.aspx.

35. Committee on Economic, Social and Cultural Rights (CESCR), "General Comment 7, The right to adequate housing (art 11.1 of the Covenant) and forced evictions" (Sixteenth session, 1997), U.N. Doc. E/1998/22, paras 8, 11, 14, http://www.unhchr.ch/tbs/doc. nsf/\%28symbol\%29/CESCR+General+Comment+7. En?OpenDocument.

36. CESCR, "General Comment 7", ibid., paras 13, 15-16; see also Miloon Kothari, 2007, Report of the Special Rapporteur on adequate housing as a component of the right to an adequate standard of living, Annex 1 (A/HRC/4/18), Basic principles and guidelines on development-based evictions and displacement, paras 21, 43, 59-61 http://daccess-dds-ny.un.org/ doc/UNDOC/GEN/G07/106/28/PDF/G0710628. pdf?OpenElement.

37. CESCR, ibid., para 13.

38. CESCR, ibid., para 11, 13, 15; Kothari, 2007, op. cit., para $17,21,59-61$.

39. CESCR, ibid., para 16; see also Kothari, 2007, op. cit., para 43.

40. Kothari, 2007, op. cit,, para. 28.

41. CESCR, General Comment 4, paras. 10, 19; Kothari, op. cit. para. 71: "The international community bears an obligation to promote, protect and fulfil the human right to housing, land and property." 
42. Islamic Republic of Afghanistan, 2004, The Constitution of Afghanistan), articles 14, 38, 40-41, http://www.afghanembassy.com.pl/afg/images/ pliki/TheConstitution.pdf.

43. Applicable not necessarily just in criminal legal context, but also, for example, in cases when inhabitants refuse to vacate (upon receiving oral notices) their homes/premises intended for demolition.

44. The former Special Rapporteur on the Right to Adequate Housing, Miloon Kothari, questions remain whether article 14 provides "clear recognition of the right of everyone to adequate housing, particularly since the Constitution is not clear as to the prevalence of international human rights law in case of conflict with the Constitution or national law," Kothari, 2004, op. cit., para. 23.

45. See article 3 of the Constitution.

46. See for example, Qur'an $2^{\text {nd }}$ sura (Baqarah) verse 85 (2:85), 24 $4^{\text {th }}$ sura (An-Nur) verses 27-28 (24:27, 24:28) and article 1216 of Majallat Al-Ahkam Adaliyya (Afghanistan-wide Hanafi school jurisprudence codified in 1876).

47. CESCR, General Comment 7, op. cit, para. 9.

48. Under the LML (2008) the term "state lands" refers to government property, public land and land over which private ownership is not proven.

49. USAID/LARA, Draft LML amendments, 18 December 2012 (text provided by USAID LARA project)

50. Wiley 2013, op. cit., p.44.

51. See Chapter 3, article 10.1 and 10.2 of the last version from July 2013 (not published, on file with MUDA).

52. See for example, articles 7,11 and 12. The draft 17 article law was passed by the Wolesi Jirga (lower house of parliament) in September 2013 and is currently being considered by the upper house (draft law not publicly available but on file with NRC).

53. See article 1 of the Decree on Land Distribution for Housing to Eligible Returnees and IDPs - No. 104, issued by the President of the Islamic Republic of Afghanistan on 6 December 2005, available at: http://morr.gov.af/Content/Media/Documents/ Presidentialdecree104218201110421115553325325.pdf.
54. NRC/IDMC/Samuel Hall/JIPS, op. cit., p.49.

55. NRC Afghanistan, Guidance Note on Presidential Decree 104, March 2010, unpublished, on file with NRC/IDMC; see also article 2 of Decree 104 and Ingrid Macdonald, Landlessness and Insecurity: Obstacles to Reintegration in Afghanistan, Middle East Institute Foundation pour la Recherche Strategique (MEI-FRS), February 2011, pp. 5-6, http://www.refugeecooperation. org/publications/Afghanistan/04_macdonald.php.

56. For details, see annexed description of the case.

57. For details, see annexed description of the case.

58. CESCR, General Comment 7, op. cit., para 8; Office of the High Commissioner for Human Rights (OHCHR) , "Fact-Sheet No. 25, Forced Evictions and Human Rights," May 1996, p.4, http://www.ohchr.org/ Documents/Publications/FactSheet25en.pdf.

59. See, for example, Aga Khan Trust, op. cit., pp. 88-96.

6o. Wily 2013, op. cit., p. 61.

61. Afghanistan Housing Land and Property Task Force (HLP TF), Minutes of HLP Task Force, Kabul, September 2013 https://afg.humanitarianresponse. info/sites/afg.humanitarianresponse.info/files/ events/minutes/HLP\%20TF\%20National\%20 Coordination\%20Meeting\%20Minutes\%2024092013. pdf

62. http://www.undp.org.af/publications/Key Documents/ANDS_Full_Eng.pdf.

63. Islamic Republic of Afghanistan, Policy on Upgrading of Informal Settlements in Afghanistan, July 2013, http://www.idlg.gov.af/eng/GDMA.

64. Kothari, 2004, op. cit., para 91.

65. IDMC, 2013, Afghanistan: Comprehensive response urgently required as displacement crisis worsens, $\mathrm{p}$. 9. http://www.internal-displacement.org/8025708 Foo4CEgoB/\%28httpCountries\%29/DFADB5842 F9262BF802570A7004BA6Fo?OpenDocument 


\section{About IDMC}

The Internal Displacement Monitoring Centre (IDMC) is a world leader in the monitoring and analysis of the causes, effects and responses to internal displacement. For the millions worldwide forced to flee within their own country as a consequence of conflict, generalised violence, human rights violations, and natural hazards, IDMC advocates for better responses to internally displaced people, while promoting respect for their human rights.

IDMC is part of the Norwegian Refugee Council (NRC).

Internal Displacement Monitoring Centre Norwegian Refugee Council

Chemin de Balexert 7-9

$\mathrm{CH}-1219$ Châtelaine (Geneva)

Tel: +4122799 0700, Fax: +41227990701

\section{About NRC}

The Norwegian Refugee Council (NRC) works to protect the rights of displaced and vulnerable persons during crisis. NRC's programmes provide assistance to meet immediate humanitarian needs, prevent further displacement and contribute to durable solutions. NRC advocates for rights to be upheld and lasting solutions achieved. Through its stand-by rosters, NRC provides expertise as a strategic partner to the UN, as well as to national and international actors.

NRC has been active in Afghanistan since 2003.

Norwegian Refugee Council PO Box 6758 St. Olavs plass, 0130 Oslo, Norway Tel: +4723109800 Fax: +47 23109801

\section{WWW.nrc.no}

\section{www.internal-displacement.org}

(3) facebook.com/norwegianrefugeecouncil

3 twitter.com/NRC_Norway

ff facebook.com/InternalDisplacement

3) twitter.com/idmc_geneva 